Plass, A.M.C., Verbeek, D.A.M., Hemminga, M., Westerman, M., Cornel, M.C. Ervaringen van ouders rond de uitslag 'drager van sikkelcelziekte' van hun pasgeboren baby naar aanleiding van de per 1 januari 2007 uitgebreide hielprik. TSG: Tijdschrift voor

Gezondheidswetenschappen: 2009, 87(3), 118-125

\begin{tabular}{|l|l|}
\hline $\begin{array}{l}\text { Postprint } \\
\text { Version }\end{array}$ & 1.0 \\
\hline Journal website & $\underline{\text { http://www2.bsl.nl/corp/common/framecreator.asp?ak=welkom\&ap=vakb\&altp=ht }}$ \\
\hline tp://vb23.bsl.nl/frontend/default.asp?product id=1388-7491 \\
\hline Pubmed link &
\end{tabular}

This is a NIVEL certified Post Print, more info at http://www.nivel.eu

\title{
Ervaringen van ouders rond de uitslag 'drager van sikkelcelziekte’ van hun pasgeboren baby naar aanleiding van de per 1 januari 2007 uitgebreide hielprik
}

\author{
AnNe MARIE C. Plass ${ }^{*}$,DEANIE A.M. VERBEeK ${ }^{* * *}$, MiCHELle HEMMINGA $^{* * *}$, MARJAN \\ WESTERMAN $^{* * * *}$, MARTINA C. CORNEL ${ }^{*}$ \\ * Afdeling Klinische Genetica: sectie Community Genetics; VU medisch centrum, Amsterdam \\ ** EMGO-instituut; VU medisch centrum, Amsterdam \\ *** Faculteit der Aard- en Levenswetenschappen, afdeling Gezondheidswetenschappen; \\ Vrije Universiteit, Amsterdam

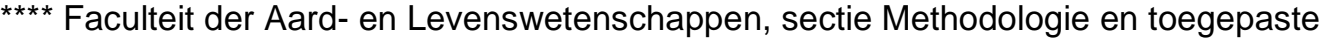 \\ Biostatistiek; Vrije Universiteit, Amsterdam \\ Mevr. A.M.C. Plass, afd. Klinische Genetica: Community genetics, EMGO-Instituut, VU \\ medisch centrum Amsterdam, Van der Boechorststraat 7, 1081 BT Amsterdam, tel: 020- \\ 4448729, e-mail: amc.plass@vumc.nl
}

Een van de nieuw toegevoegde aandoeningen in de per 1 januari 2007 uitgebreide hielprik is sikkelcelziekte. Behalve zieke kinderen worden ook dragers van deze aandoening opgespoord. Op het hielprikkaartje kunnen ouders de mogelijkheid aankruisen om niet te worden geïnformeerd over dragerschap van sikkelcelziekte van hun kind ('opt out'). Doel van dit onderzoek is om na te gaan hoe het informeren over de nieuwe hielprikuitslag 'drager van sikkelcelziekte' vanaf de zwangerschap en het meedelen van de uitslag in de praktijk verloopt en of het beoogde doel wordt bereikt. Ouders wiens pasgeboren kind (maart-september 2007) als drager van sikkelcelziekte is gediagnosticeerd, werden via de Entadministratie (Utrecht en Noord-Holland) uitgenodigd om deel te nemen aan een kwalitatief semi-gestructureerd interview. Van de 48 uitgenodigde ouderparen, reageerden negentien positief; uiteindelijk zijn dertien interviews gehouden. Ouders bleken niet op de hoogte van de 'opt out' mogelijkheid om niet geïnformeerd te worden over mogelijk dragerschap van het kind. De dragerschapuitslag werd telefonisch of middels een brief aan de ouders meegedeeld door de entadministratie of huisarts. Dit leidde tot onduidelijkheid en onrust bij de ouders die geschrokken reageerden. $\mathrm{Na}$ informatie te hebben ingewonnen maakte men zich minder zorgen, hoewel de term dragerschap niet altijd duidelijk was. De meeste ouders relateerden de 
Plass, A.M.C., Verbeek, D.A.M., Hemminga, M., Westerman, M., Cornel, M.C. Ervaringen van ouders rond de uitslag 'drager van sikkelcelziekte' van hun pasgeboren baby naar aanleiding van de per 1 januari 2007 uitgebreide hielprik. TSG: Tijdschrift voor

Gezondheidswetenschappen: 2009, 87(3), 118-125

uitslag vooral aan consequenties voor het kind, maar niet aan mogelijke reproductieve gevolgen voor henzelf. Het beoogde doel van het informeren over dragerschap van sikkelcelziekte bij pasgeborenen: geïnformeerde keuzes bij een volgende zwangerschap mogelijk te maken voor 'ouder-dragerparen', wordt (nu nog) niet bereikt.

\section{INLEIDING}

Sinds 1 januari 2007 is het nationale screeningsprogramma voor pasgeborenen uitgebreid van drie naar zo'n zeventien aandoeningen. De aandoeningen waarop gescreend wordt zijn alle behandelbare aandoeningen waarbij vroege opsporing aanzienlijke gezondheidswinst voor de pasgeborene oplevert en waarvoor een betrouwbare en valide test bestaat. ${ }^{1}$ Een van de recent toegevoegde aandoeningen is sikkelcelziekte.

Sikkelcelziekte of sikkelcelanemie, is een ernstige vorm van bloedarmoede waarbij orgaanschade ontstaat en de levensverwachting van het zieke individu beperkt is. ${ }^{2}$ Sikkelcelziekte kenmerkt zich door aanwezigheid van het afwijkende, gepolymeriseerde Hemoglobine S waardoor de cel een sikkelvorm krijgt en sneller afgebroken wordt dan normale bloedcellen. Hierdoor ontstaat bloedarmoede, maar ook klonteren de sikkelvormige cellen soms samen waardoor vaten verstopt raken en doorbloedingsstoornissen van de organen en weefsels ontstaan. ${ }^{3}$ In Nederland worden jaarlijks ongeveer 60 kinderen geboren met een vorm van erfelijke bloedarmoede (sikkelcelziekte ( 70\%) en thallassemie ( 30\%)). ${ }^{4}$ Hoe vroeger de behandeling start des te beter de levenskwaliteit en levensverwachting. Vroege opsporing is daarom belangrijk. ${ }^{2}$

Sikkelcelziekte is een autosomaal recessieve aandoening. Dit houdt in dat het kind van beide ouders een gemuteerde eigenschap moet erven om ziek te worden.

Sikkelcelziekte komt vooral vaak voor bij mensen die van oorsprong afkomstig zijn uit de gebieden rond de Middellandse Zee, Afrika, Zuid en Midden Amerika (Caraibisch gebied) en delen van Zuid-Oost Azië. ${ }^{5,6}$ Dragers van sikkelcelziekte, die slechts één gemuteerde eigenschap van hun ouders geërfd hebben, naast een andere gezonde eigenschap, zijn niet ziek maar wel beter beschermd tegen malaria. Een neveneffect van de toevoeging van sikkelcelziekte aan de hielprik, door de gekozen opsporingstechniek (HPLC), is dat niet alleen kinderen met deze ziekte, maar ook dragers worden opgespoord. Het uitvoeren van dragerschaptesten bij minderjarigen wordt in het algemeen afgeraden. ${ }^{7}$ Geadviseerd wordt om kinderen pas te testen op dragerschap wanneer zij oud genoeg zijn om de consequenties daarvan te begrijpen. ${ }^{8}$ Het meedelen van het dragerschap van sikkelcelziekte van het kind aan de ouders kent echter een groot voordeel, maar dit betreft vooral de ouders en niet zozeer het kind zelf. Naar aanleiding van het bij het kind vastgestelde dragerschap kunnen de ouders na gaan of zij mogelijk allebei drager zijn ('dragerpaar'). Immers, wanneer een kind drager is van een recessieve aandoening, zoals sikkelcelziekte, moet tenminste één van de ouders drager zijn, maar ook kunnen beide ouders drager zijn en bestaat er bij iedere volgende zwangerschap een kans van 25\% dat het kind sikkelcelziekte krijgt. Door dragerparen te informeren over hun risico, kunnen zij een geïnformeerde reproductieve keuze maken ten aanzien van toekomstige kinderen. Zij kunnen bijvoorbeeld prenataal onderzoek laten verrichten, of afzien van het krijgen van (volgende) kinderen. ${ }^{9}$ Daarnaast 
Plass, A.M.C., Verbeek, D.A.M., Hemminga, M., Westerman, M., Cornel, M.C. Ervaringen van ouders rond de uitslag 'drager van sikkelcelziekte' van hun pasgeboren baby naar aanleiding van de per 1 januari 2007 uitgebreide hielprik. TSG: Tijdschrift voor

Gezondheidswetenschappen: 2009, 87(3), 118-125

zouden ook andere familieleden zich kunnen laten testen op dragerschap. ${ }^{10,11} \mathrm{Op}$ deze wijze worden dragers steeds vaker geïnformeerd en neemt de onbekendheid rond dit onderwerp af.

Er zijn echter ook nadelen verbonden aan het meedelen van dragerschap van het kind aan de ouders. Allereerst wordt aan het recht op privacy, autonomie en het recht om niet te weten van het kind, dat zelf niet direct baat heeft bij informatie over dragerschap, voorbij gegaan. ${ }^{11}$ Ook kunnen er psychologische nadelen voor het kind worden genoemd, zoals lage zelfwaardering en stigmatisatie, ${ }^{11}$ hoewel ook psychologische voordelen zijn gerapporteerd. ${ }^{5,6}$ Daarnaast kunnen zorgen ontstaan bij de ouders over de toekomstige reproductieve mogelijkheden van het kind zelf, of (onterechte) zorgen over de gezondheid van het kind. ${ }^{10}$ Ten slotte kan ook aan het licht komen dat de vermeende vader niet de biologische vader is. ${ }^{10}$

Vanwege deze voor- en nadelen en op basis van het advies van de Gezondheidsraad, ${ }^{1}$ is in Nederland besloten om aan de ouders zelf de keus te laten of zij willen weten of hun kind drager is van sikkelcelziekte. De ouders moeten hierover voorafgaand aan de hielprik worden geïnformeerd. Wanneer zij de uitslag omtrent het dragerschap niet wensen, kunnen zij dit aankruisen op het hielprikkaartje ('opt-out'). ${ }^{12}$

Voor de praktijk betekent dit dat ouders goed geïnformeerd moeten worden over de mogelijkheid om aan te geven dat zij over dragerschap van hun kind niet willen worden geïnformeerd. Om die keus te kunnen maken dienen ouders zich te realiseren dat dragerschap niet de ziekte impliceert. Tijdens de zwangerschap ontvangen ouders informatie over de hielprik van de verloskundige zorgverlener tezamen met, of in de vorm van, een folder. ${ }^{13}$ In de folder staat dat de hielprik is uitgebreid naar zeventien aandoeningen waarop getest wordt. Ook beschrijft de folder de mogelijkheid tot opsporing van dragerschap van sikkelcelziekte van het kind en de mogelijkheid die ouders hebben om ervoor te kiezen om dat niet te willen weten. Bij de afname van de hielprik wordt deze informatie nog eens herhaald door de uitvoerder van de hielprik. Ook dient deze expliciet aan de ouders te vragen of zij de uitslag over mogelijk dragerschap van het kind wensen te ontvangen. ${ }^{12}$

Indien de ouders de uitslag wensen en het kind vervolgens drager van sikkelcelziekte blijkt te zijn, dan moet dit door de huisarts, middels een huisbezoek, worden meegedeeld waarbij de huisarts de ouders informeert over de precieze betekenis van de uitslag voor zowel het kind als voor henzelf. ${ }^{14}$ De manier waarop de boodschap aan de ouders wordt meegedeeld is bepalend voor de wijze waarop de ouders het bericht zullen interpreteren. ${ }^{15}$ Het op een verkeerde manier meedelen van de uitslag dragerschap kan leiden tot de misvatting bij de ouders dat het kind ziek is. Parsons et al (2003) rapporteerden dat ouders naar aanleiding van een op onjuiste wijze meegedeelde afwijkende hielprikuitslag ('drager van Cystische Fibrose' (CF)), spraken van een traumatische ervaring, een schokkende gebeurtenis en gevoelens van angst. ${ }^{16}$ Het draaiboek 'Neonatale hielprikscreening' vermeldt daarom expliciet middels de checklist 'voorlichtingsgesprek dragerschap sikkelcelziekte' voor de huisarts, ${ }^{14}$ dat eerst het positieve nieuws dat het kind geen sikkelcelziekte heeft en dit ook niet zal krijgen, gebracht moet worden, gevolgd door het bericht dat 'dragerschap van sikkelcelziekte' geen consequenties heeft voor de gezondheid van het kind.

Tijdens de zwangerschap ontvangen ouders een veelheid aan informatie. Daarnaast is dragerschap voor velen een moeilijk begrip, dat ook door de huisarts niet eenvoudig te duiden is. Bovendien zijn de opgespoorde dragers veelal afkomstig uit de 
Plass, A.M.C., Verbeek, D.A.M., Hemminga, M., Westerman, M., Cornel, M.C. Ervaringen van ouders rond de uitslag 'drager van sikkelcelziekte' van hun pasgeboren baby naar aanleiding van de per 1 januari 2007 uitgebreide hielprik. TSG: Tijdschrift voor

Gezondheidswetenschappen: 2009, 87(3), 118-125

Nederlandse migrantenpopulatie, waardoor mogelijke beperkte beheersing van de Nederlandse taal tot problemen bij het op juiste wijze overbrengen van informatie en mogelijke uitslag kan leiden. Dat roept de vraag op hoe de huidige

informatievoorziening rond 'dragerschap van sikkelcelziekte' in de praktijk verloopt en hoe deze uitslag door de ouders van het betreffende kind wordt ervaren.

\section{METHODE}

Om inzicht te verkrijgen in de procedures rond de per 1 januari 2007 uitgebreide hielprik in relatie tot de uitslag drager van sikkelcelziekte is gebruik gemaakt van kwalitatieve semi-gestructureerde, 'face-to-face', diepte-interviews volgens de IPAmethode waarbij zowel de inhoud van de kwalitatieve data wordt weergegeven, als gezocht wordt naar onderliggende cognitieve en emotionele concepten. ${ }^{17}$ In de interviews kwam een aantal thema's aan bod: de informatievoorziening voorafgaand aan en tijdens de hielprik, bekendheid met de mogelijkheid tot 'opt-out', de wijze van meedelen van de uitslag 'dragerschap', de informatievoorziening rond het krijgen van de uitslag, de gevolgen voor de ouders en het kind, en de ervaren emoties rondom het krijgen van de uitslag.

\section{Populatie}

De onderzoekspopulatie bestond uit ouders uit de regio's Utrecht en Noord-Holland die tussen 1 maart 2007 en 1 september 2007 een kind hadden gekregen dat middels de hielprik was opgespoord als drager van sikkelcelziekte. Om opstartproblemen in de eerste maanden waarin de uitgebreide hielprik werd geïntroduceerd te vermijden is voor 1 maart gekozen als startdatum. Omdat de interviews werden gehouden in oktober 2007, is er voor gekozen om geen ouders te includeren wiens kind later dan 1 september 2007 werd geboren. Een andere voorwaarde voor deelname aan het onderzoek was een voldoende beheersing van de Nederlandse of Engelse taal.

\section{Procedure}

Alle ouders van een in Utrecht of Noord-Holland als drager van sikkelcelziekte opgespoorde baby ontvingen een brief van de 'Stichting Entadministratie Utrecht \& Noord-Holland' met daarin de uitnodiging om deel te nemen aan het onderzoek van het VU medisch centrum Amsterdam (VUmc) naar ervaringen rondom de uitslag dragerschap op basis van de hielprik. Ouders die wilden deelnemen konden een antwoordformulier met daarop hun contactgegevens in een portvrije enveloppe sturen naar het VUmc. Op deze wijze waren de adresgegevens van de overige ouders niet bij het VUmc bekend en wist de 'Stichting Entadministratie Utrecht \& NoordHolland' niet welke ouders deelname hadden toegezegd. Na twee weken werd de uitnodiging tot deelname aan het onderzoek aan alle betreffende ouders herhaald. De onderzoekers (DV \& MH) namen telefonisch contact op met ouders die wilden deelnemen en maakten een afspraak voor een interview bij de deelnemers thuis. De afspraak werd per brief bevestigd. Het interview duurde ongeveer een uur. Elk interview werd uitgevoerd door een individuele interviewer (DV of $\mathrm{MH}$ ). Als dank voor het interview ontvingen de deelnemers na afloop een doos met chocolaatjes.

\section{Analyse}

Alle interviews werden op tape opgenomen, volledig uitgetypt en voorzien van een memo met persoonlijke indrukken van de interviewers. De transcripten zijn vervolgens geanalyseerd door beide interviewers/onderzoekers (DV \& MH) afzonderlijk, door relevante tekstdelen te voorzien van codes waardoor categorieën 
Plass, A.M.C., Verbeek, D.A.M., Hemminga, M., Westerman, M., Cornel, M.C. Ervaringen van ouders rond de uitslag 'drager van sikkelcelziekte' van hun pasgeboren baby naar aanleiding van de per 1 januari 2007 uitgebreide hielprik. TSG: Tijdschrift voor

Gezondheidswetenschappen: 2009, 87(3), 118-125

konden worden vastgesteld. De categorieën werden door de beide onderzoekers bediscussieerd tot er consensus was over de gekozen categorieën. Vervolgens werden de categorieën bediscussieerd met een derde onafhankelijke onderzoeker (AP) die alleen de transcripten had doorgelezen. Volledige overeenstemming werd bereikt over de volgende (hoofd-) categorieën: (1) informatievoorziening (tijdens de zwangerschap, tijdens de afname van de hielprik en bekendheid met de 'opt-out' mogelijkheid); (2) de uitslag (communicatie van de uitslag, informatie bij de uitslag en ervaringen van de ouders rondom de uitslag ); (3) interpretatie en consequenties dragerschap (reproductieve consequenties kind en ouders (interpretatie van de uitslag ‘dragerschap' en ervaren consequenties van die uitslag).

\section{RESULTATEN}

\section{Populatie}

In de periode maart 2007-augustus 2007 werden er in de provincies Utrecht en Noord-Holland middels de hielprik 48 dragers van sikkelcelziekte opgespoord. Negentien ouderparen reageerden positief op de uitnodiging tot deelname aan het onderzoek: van twee ouderparen waren de op het antwoordformulier ingevulde contactgegevens niet toereikend om daadwerkelijk contact met hen te kunnen leggen, een ouderpaar bleek niet thuis op het moment van afspraak, drie ouderparen reageerden nadat de periode waarin de interviews werden gehouden al was afgerond. Uiteindelijk werden er dertien interviews afgenomen, in de periode eind oktober/ begin november 2007, waaronder twee in het Engels. Er waren twintig ouders betrokken bij de interviews: bij zeven waren beide ouders aanwezig, bij vier alleen de moeder en in twee gevallen alleen de vader. In het totaal ging het om veertien kinderen: twaalf eenlingen en een tweeling (beide kinderen drager). Demografische variabelen zijn weergegeven in tabel 1.

\section{[TABEL 1]}

\section{Informatievoorziening}

\section{Informatie tijdens de zwangerschap}

De geïnterviewde ouders gaven aan dat zij voor en tijdens de zwangerschap onbekend waren met zowel sikkelcelziekte, als dragerschap, met uitzondering van een ouderpaar dat al voor de zwangerschap op de hoogte was van het dragerschap van de vader. Desalniettemin vertelden drie ouders dat zij tijdens de zwangerschap door de verloskundige waren geïnformeerd over de hielprik, het doel daarvan, de wijze van afname, maar ook over de uitbreiding van het aantal aandoeningen waarop getest wordt. Sikkelcelziekte kwam daarbij niet specifiek aan de orde. Zij herinnerden zich niet dat over dragerschap werd gesproken. Twee andere ouders herinnerden zich een folder over de hielprik die zij tijdens de zwangerschap hadden gekregen. Deze ouders wezen echter tegelijkertijd op het feit dat er tijdens de zwangerschap veel informatie werd aangeboden waardoor het niet mogelijk was om aandacht te besteden aan alle informatie.

"Dat kregen wij volgens mij van het Ministerie van Volksgezondheid. In ieder geval een brief met allemaal folders. Je moet zoveel lezen en op een gegeven moment onthoud je niet alles." 
Plass, A.M.C., Verbeek, D.A.M., Hemminga, M., Westerman, M., Cornel, M.C. Ervaringen van ouders rond de uitslag 'drager van sikkelcelziekte' van hun pasgeboren baby naar aanleiding van de per 1 januari 2007 uitgebreide hielprik. TSG: Tijdschrift voor

Gezondheidswetenschappen: 2009, 87(3), 118-125

Informatie tijdens de afname van de hielprik

De helft van de geïnterviewde ouders wist zich te herinneren dat de uitvoerder van de hielprik (vaak de wijkverpleegkundige) had gesproken over het feit dat er nu op zeventien aandoeningen getest zou worden. Volgens de ouders was het testen op dragerschap niet besproken.

"Niet specifiek over sikkelcelziekte, maar wel dat ze de hielprik ging afnemen omdat ze dus kinderziektes op een vroeg stadium willen oppakken zeg maar. En het ging dan om zeventien verschillende soorten kinderziektes die ze dan daarmee naar voren kunnen laten komen. Maar ze heeft niet specifiek verteld wat die ziektes zijn”.

"Nee niet op dragerschap. Nee, daar heeft ze het niet over gehad. Ze heeft alleen gezegd dat er getest werd op sikkelcelziekte”.

De overige ouders herinnerden zich niet dat de uitvoerder van de hielprik hen mondeling geïnformeerd had over de hielprik. Een aantal ouders kreeg wel een folder van de uitvoerder van de hielprik waarin het doel en de wijze van afname van de hielprik werden beschreven

"Nee, er heeft vooraf geen gesprek plaats gevonden".

"Ja, ja ik kreeg inderdaad een stapeltje folders mee".

Ouders die geen of slecht Nederlands spraken, kregen naar eigen zeggen minder of geen informatie voorafgaand aan de afname van de hielprik.

\section{'Opt-out'}

Geen van de geïnterviewde ouders was zich bewust van de mogelijkheid om op het hielprikkaartje aan te kruisen dat zij niet geïnformeerd wilden worden over mogelijk dragerschap van sikkelcelziekte van hun kindje.

"Nee, want kan dat wel?!".

Een ouderpaar had, vanwege het dragerschap van de vader, expliciet gevraagd om het kind op dragerschap te testen. Dit zag men als oorzaak dat over de 'opt-out' mogelijkheid niet met hen was gesproken. Ondanks dat men niet op de hoogte was van de mogelijkheid om niet over mogelijk dragerschap van het kind te worden geïnformeerd, waren de meeste ouders wel blij dat ze hierover geïnformeerd werden. Enkele ouders hadden echter liever niet geweten dat hun kind drager is van sikkelcelziekte.

"Ik vind het wel goed dat ze erop testen, anders had ik het nooit geweten..."

"Naar mate ik meer informatie krijg, ga ik er ook meer over nadenken"

[interpretatie: meer zorgen maken (AP)]

De afname van de hielprik zelf werd door de meeste ouders beschouwd als iets dat eenmaal zo hoort na de geboorte. In een geval hadden de ouders bezwaar tegen de afname van de hielprik, dit werd echter 'overruled' en de hielprik werd desondanks afgenomen.

“Ja, ze zeggen dat het normaal, een gewoonte is. De kinderen worden geprikt om te kijken of ze wat hebben."

"Nou, ik vind het fijn om te weten als ze iets mankeren, want dan ben je er vroeg bij."

"Maar ik wilde niet dat zij bloed afnamen... Ze zeiden dat dat zo werd gedaan in Nederland. Maar we hadden simpelweg geen keuze, elke dag kwam er iemand [in het ziekenhuis, waar de baby wegens complicaties bij de geboorte was opgenomen (AP)] om ons te vertellen over de noodzaak van de test. Ze dwongen ons om een keuze te maken,...” 
Plass, A.M.C., Verbeek, D.A.M., Hemminga, M., Westerman, M., Cornel, M.C. Ervaringen van ouders rond de uitslag 'drager van sikkelcelziekte' van hun pasgeboren baby naar aanleiding van de per 1 januari 2007 uitgebreide hielprik. TSG: Tijdschrift voor

Gezondheidswetenschappen: 2009, 87(3), 118-125

\section{De Uitslag}

\section{Ervaren emoties}

De ouders reageerden geschokt en/of verbaasd op de uitslag die zij niet hadden verwacht, mede doordat men nog nooit had gehoord van testen op dragerschap van sikkelcelziekte. Ook ouders die wel rekening hielden met een ongunstige uitslag reageerden geschrokken.

"Ik vond het verschrikkelijk en ben in het begin erg geschrokken."

\section{Gezinssamenstelling}

Ouders die al een of meer kinderen hadden voor de geboorte van het huidige kind waren extra verrast door het feit dat de hielprik iets had aangetoond bij hun pasgeboren zoon of dochter, omdat dit bij hun overige kinderen niet aan de orde was geweest. Daarbij realiseerde men zich niet dat de overige kinderen evenzogoed drager van sikkelcelziekte kunnen zijn.

"Ik heb het nooit bij die anderen gehad van dat ik een brief thuis kreeg van er is iets ontdekt, maar bij deze wel en dan schrik je wel van oh nee wat is er nou aan de hand en al die toestanden."

"Ja, ja gewoon dat zij een brief kreeg dat er bij haar ernstige bloedarmoede is ontdekt. Alleen de uitslag van deze was heel anders dan bij de jongens.”

Dit laatste citaat toont evenals onderstaande citaten ook aan dat dragerschap makkelijk wordt verward met de ziekte.

"Daarna vertelden zij [de artsen in het ziekenhuis; AP] dat hij een soort van ziekte heeft geërfd van ons en wij vroegen wat wij ertegen konden doen."

"Uhm..zij proberen..mij te vertellen dat deze ziekte bij ons is. En dat het kindje dit heeft en een van ons ook drager is."

Ook is onduidelijk wat dragerschap betekent en of het kind nu wel of niet iets heeft. Daarnaast leidt het feit dat er op dragerschap getest wordt terwijl dit niet te genezen is tot onbegrip.

"Wij verwachtten een gezond kindje. Hij is wel gezond, want hij is wel drager. Maar toch."

"Ja hij heeft iets maar het is niets, weet je wel."

"Dus wij vroegen aan de doktoren jullie kunnen toch niets doen, waarom moesten wij dan het bloed afstaan om vervolgens iets te kunnen genezen. Zoek een medicijn, en nu vertel je me dat je niks kunt doen?! ...het is allemaal waardeloos..."

\section{Meedelen afwijkende hielprikuitslag}

Anders dan het protocol ${ }^{14}$ voorschrijft werd de afwijkende hielprik uitslag 'drager van sikkelcelziekte' niet door de huisarts middels een huisbezoek overgebracht, maar per brief of telefoon. In de meeste gevallen gebeurde dit door de entadministratie omdat de huisarts van het kind in kwestie niet altijd bekend was. De op deze wijze meegedeelde uitslagen leidden tot grote schrik en veel zorgen, onder andere omdat de op deze wijze verkregen informatie beperkt of onduidelijk was. Sommige ouders namen daarop zelf contact op met de huisarts.

"Het was wel even schrikken toen ik een brief thuis kreeg, want ik wist helemaal niet of zij er ziek van werd of zo"

"Ze hebben mij gebeld van de hielprik administratie,.... Toen ben ik dus heel erg geschrokken, want ik had eigenlijk niks verwacht." 
Plass, A.M.C., Verbeek, D.A.M., Hemminga, M., Westerman, M., Cornel, M.C. Ervaringen van ouders rond de uitslag 'drager van sikkelcelziekte' van hun pasgeboren baby naar aanleiding van de per 1 januari 2007 uitgebreide hielprik. TSG: Tijdschrift voor

Gezondheidswetenschappen: 2009, 87(3), 118-125

Ook wanneer de huisarts wel de boodschapper was werd de uitslag per brief of telefonisch overgebracht, soms gevolgd door een huisbezoek. In een geval leidde het huisbezoek van de huisarts tot commotie, omdat daar een brief aan was voorafgegaan waarin stond dat het kind gezond was. Tenslotte had een ouderpaar, voor zover zij wisten, helemaal geen uitslag ontvangen en werden zij in kennis gesteld van de uitslag door de uitnodigingsbrief voor onderhavig onderzoek door het VUmc. "Ze hebben me alleen een brief gestuurd. Het is de brief die jij [onderzoeker VUmc (AP)] of het ziekenhuis [VUmc (AP)] mij gestuurd hebt. Ik moest het formulier invullen en zij hebben mij verteld dat ze drager is van sikkelcelziekte."

\section{Aanvullende informatie}

Doordat de meeste ouders de uitslag niet hadden verwacht en daardoor schrokken, resulteerde dit in de meeste gevallen tot directe zorgen over het kindje. Echter naarmate men meer over het onderwerp had opgezocht via Internet, of voorlichting had ontvangen door de huisarts, werd men geruster over de uitslag. De informatie verkregen via het Internet werd daarbij beter gewaardeerd dan de informatie die de huisarts gaf. Vooral de hoger opgeleide ouders zochten zelf informatie.

“Ja, we zijn wel bezorgd, maar als wij horen dat het niet zo erg is en dat zij niet ziek is, dan geen zorgen."

"Maar we gingen zelf wel even op Internet 'Googlen' van wat het nou precies, en wat houdt het in en wat zijn de gevolgen."

"Ik denk dat als ik niets van had geweten, dat ik de voorlichting [van de huisarts $(A P)]$ niet goed had gevonden. Dus denk ik dat ik misschien in paniek was geraakt of heel erg bang geworden of wat dan ook. Als je helemaal niets vanaf weet en ook niet handig bent met Internet dat je daarvan kan schrikken. Ik denk dat de informatie beter had gekund."

Ouders die alleen via de huisarts informatie hadden gekregen en niet op het Internet hadden gezocht wisten nog steeds niet goed waar ze aan toe waren.

\section{Interpretatie en consequenties dragerschap}

\section{Reproductieve consequenties}

Uit de interviews kwam naar voren dat naar aanleiding van de hielprikuitslag 'drager van sikkelcelziekte' vooral de consequenties voor het kind zelf waren besproken door de huisarts. De ouders waren zeer goed op de hoogte van de gevolgen van dragerschap voor het kind wanneer dit in de toekomst zelf kinderen zou willen krijgen.

"In haar geval moet ze ook extra aandacht besteden aan haar toekomst. Als ze met een man wil trouwen die ook drager is. Dus we zullen het haar vertellen wanneer ze het zal begrijpen."

“...als ze thuis komt met een vriend die ook drager is dan wijzen wij hem de deur....”

\section{Reproductieve consequenties ouders}

Meer dan de helft van de ouders was bekend met de reproductieve consequenties voor henzelf in relatie tot een eventueel volgend kind. Ouders die zelf informatie hadden gezocht bleken beter op de hoogte van de eigen reproductieve consequenties dan ouders die dit niet hadden gedaan. Voor één ouderpaar werden de consequenties voor henzelf duidelijk tijdens het interview. 
Plass, A.M.C., Verbeek, D.A.M., Hemminga, M., Westerman, M., Cornel, M.C. Ervaringen van ouders rond de uitslag 'drager van sikkelcelziekte' van hun pasgeboren baby naar aanleiding van de per 1 januari 2007 uitgebreide hielprik. TSG: Tijdschrift voor

Gezondheidswetenschappen: 2009, 87(3), 118-125

"En voor ons...ja, een van ons is drager en kan drager worden als we nog een kindje krijgen kan het weer de kans zijn. Dus ja...alhoewel wij ook alle twee drager kunnen zijn, kan het ook zijn dat we een kind kunnen krijgen die...daar had ik nog niet over nagedacht."

Desondanks werd de relatie met het zelf laten testen van de ouders op dragerschap veelal niet gelegd of begrepen. In de gesprekken met de huisarts was de noodzaak voor de ouders om zich te laten testen, conform de beschrijving in de richtlijn voor huisartsen "checklist voorlichtingsgesprek dragerschap bij sikkelcelziekte", ${ }^{14}$ niet als zodanig aan de orde gekomen. In een aantal gevallen werd door de huisarts helemaal niet gesproken over het testen van de ouders. Ouders die zich wel lieten testen begrepen niet altijd waarom. Soms deden zij dit om te bepalen van wie het kind het had gekregen. Van de ouders die zich niet wilden laten testen gaven sommigen aan de test voor zichzelf niet belangrijk te vinden, maar wel voor de overige kinderen in het gezin. Anderen beschouwden de ziekte niet als echt ernstig. Tenslotte waren er ook die zich niet lieten testen omdat zij dachten dat zij geen dragerpaar konden zijn omdat in dat geval het kind immers ziek zou zijn geweest en niet slechts drager. "Nou er stond in de brief dat een van de ouders het heeft, en dat wil je weten, van wie het vandaan komt."

"Nee, omdat ik het eigenlijk niet zal hebben, omdat me vriendin het heeft en ik het dan ook zou hebben, dan zouden ze [de kinderen] die ziekte hebben"."

"Mijn gedachten was dat het belangrijker was om mijn oudste zoon te testen, of hij drager is en voor zijn toekomst, als voor ons'."

"Maar ik moet echt eerlijk zeggen, dat de aandoening niet zodanig ernstig is dat wij zoiets hebben van dat we niet meteen naar het ziekenhuis gaan om bloed te prikken',"

"Ik weet gewoon niet hoe ik dat moet doen in het ziekenhuis en hoe ik dat moet uitleggen."

Slechts enkele ouders gaven blijk van kennis van zaken.

"Hangt af van de test of deze uitwijst of één ouder drager is of beiden. Dat heeft natuurlijk verschillende consequenties, in het nemen van meerdere kinderen."

"Nee absoluut niet (over zelf laten testen op dragerschap [AP]), want ik ben al 40 ... ik heb nu twee kinderen en dat is goed zo."

\section{Impact dragerschap}

Hoewel ouders zich zorgen maken over het kind na het horen van de uitslag 'drager van sikkelcelziekte' beperken deze zorgen zich vooral tot het heden en lijken niet of nauwelijks impact te hebben op de toekomst van het kind of het gezin waartoe het kind behoort.

"Zeg maar onze toekomst is gewoon..., misschien één of twee kinderen erbij, maar dragerschap speelt hierbij geen rol."

“Eventueel als ze topsport gaan doen, dan zouden ze er last van kunnen hebben.”

\section{DISCUSSIE}

De uitslag 'drager van sikkelcelziekte' is een nieuw soort afwijkende hielprikuitslag, die wordt doorgegeven vanwege de mogelijke reproductieve risico's van de ouders en niet zozeer ten behoeve van het kind zelf. Vanwege de onbekendheid met deze uitslag, het feit dat de uitslag vooral de ouders ten goede komt en het feit dat dragerschap een moeilijk te begrijpen begrip is, vraagt juist deze uitslag om extra 
Plass, A.M.C., Verbeek, D.A.M., Hemminga, M., Westerman, M., Cornel, M.C. Ervaringen van ouders rond de uitslag 'drager van sikkelcelziekte' van hun pasgeboren baby naar aanleiding van de per 1 januari 2007 uitgebreide hielprik. TSG: Tijdschrift voor

Gezondheidswetenschappen: 2009, 87(3), 118-125

aandacht bij het meedelen ervan. Dat leek in deze periode nog niet goed te lukken. Ook de informatievoorziening rondom de afname van de hielprik zelf behoeft nog aandacht. Gezien de korte termijn waarop de nieuwe procedure is geïmplementeerd is dit niet verwonderlijk. Gebleken is dat ouders onbekend waren met het feit dat de hielprik uitslag ook kon bestaan uit de mededeling 'drager van sikkelcelziekte'. Een afwijkende hielprik uitslag wordt als vanzelf geassocieerd met 'dat er met het kindje wat aan de hand is'. Hoewel in de folder die de ouders van de verloskundige zorgverlener hebben ontvangen tijdens de zwangerschap staat uitgelegd dat behalve ziekte van het kind bij de hielprik ook dragerschap kan worden gerapporteerd, waren de ouders hier niet van op de hoogte. Enerzijds, doordat men door de grote hoeveelheid informatie die men tijdens de zwangerschap krijgt niet alle informatie even goed op waarde kan schatten. Anderzijds, vraagt de introductie van een dergelijke nieuwe uitslag ook meer aandacht dan waaraan middels het uitdelen van een folder kan worden voldaan. ${ }^{18}$ De ouders die nu de uitslag 'drager van sikkelcelziekte' te horen kregen waren door deze uitslag verrast. Wanneer er tijdens de zwangerschap meer, maar ook explicieter, was stilgestaan bij deze nieuwe vorm van hielprikuitslag, die vooral ten behoeve van de ouders wordt doorgegeven, dan waren betreffende ouders mogelijk beter voorbereid op de uitslag geweest.

De geïnterviewde konden zich niet herinneren dat tijdens de afname van de hielprik werd gesproken over 'dragerschap van sikkelcelziekte', noch over de mogelijkheid om op het hielprikkaartje aan te kruisen dat informatie over mogelijk dragerschap van het kind niet gewenst is. Hierdoor waren de ouders niet in de gelegenheid om te kiezen voor wat zij in het beste belang van hun kind achten en wordt voorbij gegaan aan het recht op privacy en het recht om niet te weten van het kind, dat idealiter op latere leeftijd zelf zou moeten beslissen om geïnformeerd te worden over mogelijk dragerschap. Door de hielprik is deze informatie echter al bij de geboorte beschikbaar.

Ouders werden daarentegen wel uitgebreid geïnformeerd over het feit dat de hielprik was uitgebreid en dat er op meerdere aandoeningen werd getest in het directe belang van de gezondheid van het kind, terwijl dat in het geval van de uitslag 'dragerschap' niet zo is. Het is daarom niet verwonderlijk dat ouders bij het horen van de uitslag 'drager van sikkelcelziekte' direct aan de gezondheid van hun kind denken en de consequenties daarvan voor het kind zelf. Niet alle ouders begrepen daarom waarom deze test werd gedaan, nu de uitslag niet bleek te kunnen worden beïnvloed middels een behandeling of therapie. Tenslotte rapporteerde een ouderpaar dat niet aan de 'basic consent' procedure door de hielprikuitvoerders was voldaan. Hoewel de ouders het niet eens waren met de afname, werd de hielprik toch gedaan, terwijl in een dergelijk geval op het hielprikkaartje moet worden vermeld dat de ouders niet akkoord gaan, vergezeld van de reden waarom. Onbekendheid met het Nederlandse gezondheidszorgsysteem van de ouders lijkt hierbij een van de knelpunten.

De afwijkende hielprikuitslag moet conform het RIVM protocol door de huisarts middels een huisbezoek aan de ouders worden meegedeeld. ${ }^{14}$ In dat gesprek dient nadrukkelijk aan de orde te komen dat het kind geen sikkelcelziekte heeft en ook niet zal krijgen. Voorts dient door de huisarts het testen van de ouders op sikkelceldragerschap te worden besproken. In de praktijk blijkt het echter niet altijd mogelijk voor de entadministratie om de huisarts in kwestie te bereiken, zodat de entadministratie in veel gevallen de brenger van de boodschap is. Het gaat hierbij om een telefonische of schriftelijke boodschap. Wanneer de huisarts wel kan worden 
Plass, A.M.C., Verbeek, D.A.M., Hemminga, M., Westerman, M., Cornel, M.C. Ervaringen van ouders rond de uitslag 'drager van sikkelcelziekte' van hun pasgeboren baby naar aanleiding van de per 1 januari 2007 uitgebreide hielprik. TSG: Tijdschrift voor

Gezondheidswetenschappen: 2009, 87(3), 118-125

geïnformeerd door de entadministratie, dan brengt ook deze de boodschap veelal telefonisch of schriftelijk over, soms gevolgd door een huisbezoek. De informatie die de ouders krijgen van de huisarts wordt niet hoog gewaardeerd. Informatie die men op het internet vindt wel. Behalve de manier waarop de huisarts de ouders informeert, die bepalend kan zijn voor de manier waarop de uitslag wordt ervaren ${ }^{15}$ is het ontvangen van een afwijkende uitslag op zich al een gebeurtenis die de ouders door ontstane emoties minder ontvankelijk kan maken voor het opnemen en verwerken van nieuwe informatie. ${ }^{15}$ De combinatie van een huisbezoek van de huisarts samen met het verstrekken van 'links' waar op Internet goede informatie aangaande de uitslag kan worden verkregen, zou uitkomst kunnen bieden.

Ten slotte bleek het voor het merendeel van de geïnterviewde ouders niet duidelijk dat de uitslag juist hen en in mindere mate het kind zelf betrof, conform de bevindingen beschreven in het TNO rapport "Evaluatie hielprik voorlichting 2008”.

${ }^{19}$ Sommige ouders werden getest door de huisarts, maar begrepen het doel ervan niet (geheel). Andere ouders zagen om dezelfde reden af van het laten uitvoeren van een dragerschapstest. Hierdoor wordt het voordeel van het meedelen van de uitslag 'drager van sikkelcelziekte' bij pasgeboren kinderen gemist. Om er voor te zorgen dat het in de toekomst anders verloopt zijn verbeteringen nodig die een actieve benadering vragen. Deze problemen lossen zich niet vanzelf op, ook niet na de periode dat redelijkerwijs mag worden aangenomen dat de opstartfase met de daarmee gepaard gaande problemen, is verstreken.

\section{Beperkingen van de studie}

Deze studie is gestart niet lang na de invoering van de uitgebreide hielprik. De problemen die gesignaleerd zijn kunnen daardoor niet los worden gezien van de problemen die ontstaan bij het opstarten van welke nieuwe procedure dan ook. Niet alle aangeschreven ouders hebben gereageerd op het verzoek om mee te werken aan deze studie. Slechts een selecte groep gaf gehoor aan de oproep. Dit zijn mogelijk juist de ouders die een negatieve ervaring hadden en daar graag over wilden praten. Dat neemt echter niet weg dat dit een substantieel deel, meer dan een derde, van de aangeschreven populatie betrof. Ook al zouden de problemen zich tot een derde van de populatie die het betreft beperken, dan nog kan gesteld worden dat dit te veel is. De beschreven problemen zouden een uitzondering moeten vormen.

\section{DANKBETUIGING}

Van harte bedanken wij mw. Marjo Oey van de Entadministratie Utrecht en NoordHolland voor haar medewerking bij het aanschrijven van de ouders, alle deelnemende ouders en mw dr Carla van El, onderzoeker Community Genetics, afdeling Klinische Genetica, EMGO-instituut, VUmc, Amsterdam, voor haar commentaar op een eerdere versie van dit artikel.

Voor publicatie aanvaard in januari 2009.

\section{PARENTAL FEELINGS TOWARDS THE IDENTIFICATION OF THEIR INFANT AS CARRIER OF SICKLE CELL ANEMIA BY NEWBORN-SCREENING}

In 2007, the neonatal screening programme in the Netherlands was expanded with 14 disorders, one of which was sickle cell anemia. Un unintended sideeffect of this was that not only affected children could be identified, but also carriers of sickle cell anemia. The latter is not directly in the child's' best 
Plass, A.M.C., Verbeek, D.A.M., Hemminga, M., Westerman, M., Cornel, M.C. Ervaringen van ouders rond de uitslag 'drager van sikkelcelziekte' van hun pasgeboren baby naar aanleiding van de per 1 januari 2007 uitgebreide hielprik. TSG: Tijdschrift voor

Gezondheidswetenschappen: 2009, 87(3), 118-125

interest, and therefore the parents will have to decide whether or not information on their child's carrier status should be disclosed to them. If the parents would decide that they do not want any information on their child's carrier status, they could 'opt-out'. Otherwise, information on their child's carrier status would be disclosed to them. The most important reason to disclose information about a child's carrier status to the parents is to enable parents to base their future reproductive choices on this information. The aim of this study was to explore how (future) parents are being informed about this newly introduced possibility to learn more about their child's carrier status for sickle cell disease, to learn how parents perceive their child's carrier status being disclosed to them, and to see whether this information is taken into account with regard to the parents future reproductive choices.Parents of children who from March to September 2007 were diagnosed as carriers of sickle cell disease by the newborn-screening programme, ,were invited by the Dutch heel prick organisation ('Entadministratie') to take part in a qualitative semi-structured interview carried out by the VU University medical center. 48 parent-couples were invited, 19 couples accepted the invitation; eventually 13 interviews could be held. Parents were unaware of the possibility they could 'opt-out' from being informed about their child's carrier status. Initially, parents were shocked after hearing the diagnosis of their child being a sickle cell anaemia carrier, mainly because they did not know anything about it, and were not aware that their child would fall ill. Most parents looked for information on the Internet, after which they became less worried, even though most parents still did not understand the proper meaning of carriership. None of the parents linked their child's carrier status to their own future reproductive choices.The way in which information on carrier status of sickle cell anaemia is being disclosed to parents needs to be improved. The most important reason for disclosing information about their child's carrier status - to enable the parents to make future reproductive choices - is not yet being achieved.Keywords: Neonatal Screening; Sickle cell Disease; Carriership; Dissemination of information to parents

\section{LITERATUUR}

1. Gezondheidsraad. Neonatale Screening. Den Haag: Gezondheidsraad, 2005.

2. Heijboer $\mathrm{H}$, Tweel $\mathrm{X}$ van den, Fijnvandraat $\mathrm{K}$, Peters $\mathrm{M}$. Herkenning van kinderen met sikkelcelziekte in Nederland. Ned Tijdschr Geneeskd 2007;151:2498-501.

3. OSCAR Nederland. Sikkelcelziekte Symptomen en behandeling \& Erfelijkheid, preventie en zwangerschap: Brochure voor mensen die meer willen weten over sikkelcelziekte of sikkelcelanemie. Amsterdam: OSCAR Nederland, 2008.

4. Giordano PC, Plancke A, Van Meir CA et al. Carrier diagnostics and prevention of hemoglobinopathies in early pregnancy in The Netherlands: a pilot study. Prenat Diagn 2006;26:719-24.

5. Angastiniotis M, Modell B, Englezos P, Boulyjenkov V. Prevention and control of haemoglobinopathies. Bull World Health Organ 1995;73:375-86.

6. Lakeman P, Henneman L, Bezemer PD, Cornel MC, Ten Kate LP. Developing and optimizing a decisional instrument using self-reported ancestry for carrier screening in a multi-ethnic society. Genet Med 2006;8:502-9. 
Plass, A.M.C., Verbeek, D.A.M., Hemminga, M., Westerman, M., Cornel, M.C. Ervaringen van ouders rond de uitslag 'drager van sikkelcelziekte' van hun pasgeboren baby naar aanleiding van de per 1 januari 2007 uitgebreide hielprik. TSG: Tijdschrift voor

Gezondheidswetenschappen: 2009, 87(3), 118-125

7. Borry P, Fryns JP, Schotsmans P, Dierickx K. Carrier testing in minors: a systematic review of guidelines and position papers. Eur J Hum Genet 2006;14:133-8.

8. Borry P, Fryns JP, Schotsmans P, Dierickx K. Attitudes towards carrier testing in minors: a systematic review. Genet Couns 2005;16:341-52.

9. Giordano PC, Dihal AA, Harteveld CL. Estimating the attitude of immigrants toward primary prevention of the hemoglobinopathies. Prenat Diagn 2005;25:885-93.

10. Oliver S, Dezateux C, Kavanagh J, Lempert T, Stewart R. Disclosing to parents newborn carrier status identified by routine blood spot screening. Cochrane Database Syst Rev 2004;18:CD003859.

11. Borry P, Nys H, Dierickx K. Carrier testing in minors: conflicting views. Nat Rev Genet 2007;8:828.

12. RIVM. Voorlichting neonatale metabole screening: checklist uitvoerders hielprik. Bilthoven: RIVM, 2006.

13. RIVM. Voorlichting neonatale metabole screening: checklist voorlichtingsgesprek verloskundige hulpverleners. Bilthoven: RIVM, 2006.

14. RIVM. Voorlichtingsgesprek dragerschap sikkelcelziekte: checklist voor de huisarts. Bilthoven: RIVM, 2006.

15. La Pean A, Farrell MH. Initially misleading communication of carrier results after newborn genetic screening. Pediatrics 2005;116:1499-505.

16. Parsons EP, Clarke AJ, Bradley DM. Implications of carrier identification in newborn screening for cystic fibrosis. Arch Dis Child Fetal Neonatal Ed 2003;88:F467-F471.

17. Smith J. Beyond the divide between cognition and discourse; using interpretative phenomenological analysis in health psychology. Psychol Health 1996;11:261-71.

18. Parker H, Qureshi N, Ulph F, Kai J. Imparting carrier status results detected by universal newborn screening for sickle cell and cystic fibrosis in England:a qualitative study of current practice and policy challenges. BMC Health Serv Res 2007;7:203.

19. Pal S van der, Detmar S. Evaluatie hielprikvoorlichting 2008. Leiden: TNO, 2008. 
Plass, A.M.C., Verbeek, D.A.M., Hemminga, M., Westerman, M., Cornel, M.C. Ervaringen van ouders rond de uitslag 'drager van sikkelcelziekte' van hun pasgeboren baby naar aanleiding van de per 1 januari 2007 uitgebreide hielprik. TSG: Tijdschrift voor

Gezondheidswetenschappen: 2009, 87(3), 118-125

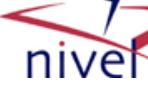

TABEL

Tabel 1 Demografische gegevens van de 20 ouders die deelnamen aan de interviews

\begin{tabular}{|c|c|}
\hline & $\mathrm{N}$ \\
\hline \multicolumn{2}{|l|}{ Sekse } \\
\hline Man & 9 \\
\hline Vrouw & 11 \\
\hline \multicolumn{2}{|l|}{ Etniciteit } \\
\hline Afrikaans & 9 \\
\hline Surinaams & 4 \\
\hline Nederlands & 4 \\
\hline Onbekend & 3 \\
\hline \multicolumn{2}{|l|}{ Opleidingniveau } \\
\hline Geen of alleen basisonderwijs & 2 \\
\hline Middelbaar (VMBO/ MBO) & 4 \\
\hline Hoger (HAVO/ VWO/ HBO) & 6 \\
\hline Universitair & 3 \\
\hline Onbekend & 5 \\
\hline \multicolumn{2}{|l|}{ Burgerlijke staat } \\
\hline Gehuwd & 7 \\
\hline Ongehuwd samenwonend & 3 \\
\hline Alleenstaand & 1 \\
\hline Onbekend & 2 \\
\hline \multicolumn{2}{|l|}{ Diagnose kind } \\
\hline Drager sikkelcelziekte & 10 \\
\hline Drager, aandoening onbekend bij ouders & 3 \\
\hline \multicolumn{2}{|l|}{ Gemiddelde leeftijd geïnterviewde ouders } \\
\hline Mannen & 32,7 jaar \\
\hline Vrouwen & 39,3 jaar \\
\hline
\end{tabular}

